\title{
Prion protein as a toxic acceptor of amyloid- $\beta$ oligomers
}

Silvia A. Purro ${ }^{1}$, Andrew J. Nicoll ${ }^{1,2^{*}}$ and John Collinge ${ }^{1 *}$

\footnotetext{
${ }^{1}$ MRC Prion Unit at UCL, UCL Institute of Prion Diseases, Queen Square, London, WC1N 3BG. UK

${ }^{2}$ Elkington + Fife LLP, Prospect House, 8 Pembroke Road, Sevenoaks, Kent, TN13 1XR. UK

*Correspondence to a.nicoll@ucl.ac.uk or jc@prion.ucl.ac.uk, phone 0044(0)2078374888.
}

Short title: $\operatorname{PrP}^{C}$ as a toxic acceptor of $A \beta$ oligomers

Abstract: 120 words.

Text: 4073 words.

Tables: 1.

Figures: 3.

Supplementary material: 0 .

Key words: prion, amyloid, Alzheimer's disease, oligomers, neurodegeneration, therapeutics. 


\section{Abstract:}

The initial report that cellular prion protein $\left(\operatorname{PrP}^{C}\right)$ mediates toxicity of Amyloid- $\beta(A \beta)$ species linked to Alzheimer's disease was initially treated with scepticism, but growing evidence supports this claim. That there is a high-affinity interaction is now clear and its molecular basis is being unravelled whilst recent studies have identified possible down-stream toxic mechanisms. Determination of the clinical significance of such interactions between $\operatorname{PrP}^{C}$ and disease-associated $A \beta$ species will require experimental medicine studies in humans. Compounds that inhibit PrP-dependent A $\beta$ toxicity are starting to be trialled in humans and, although it is clear that only a fraction of Alzheimer's disease toxicity could be governed by $\operatorname{PrP}^{\mathrm{C}}$, a partial but still therapeutically useful role in human disease may soon be testable. 


\section{Introduction}

The pathological hallmarks of Alzheimer's disease (AD) are extracellular deposition of cerebral amyloid predominantly composed of amyloid- $\beta$ protein $(A \beta)$ forming plaques and vascular deposits, and intracellular neurofibrillary tangles mainly composed of hyperphosphorylated Tau protein. $A \beta$ plaques were initially suspected to be directly toxic to neurones, although closer inspection revealed that levels of plaque deposits did not necessarily correlate with the severity of disease (1). For this reason, attention has turned to soluble oligomeric forms of $A \beta$ that appear to be more neurotoxic (2) and correlate better with disease in $A D$ patients (3). The soluble $A \beta$ forms range from monomers to high molecular weight aggregates with different properties and toxic effects (Figure 1). It is possible that distinct conformations or classes of assemblies may also possess different seeding activity $(4 ; 5)$. Similarities between Alzheimer's and prion disease have been noted for decades and the recent major growth of interest in the role of so-called "prion-like" mechanisms in other neurodegenerative diseases has led to an explosion in publications linking these diseases (6), that are beyond the scope of this review. It remains to be seen if knowledge of the misfolding and seeded aggregation processes will result in new therapeutics for sporadic forms of these diseases. However, a wider understanding of prion pathogenesis and the decades of experience built up in the prion field could facilitate AD research and the development of novel therapies (7).

$A D$ itself incorporates a mêlée of genetic and apparently sporadic conditions that can co-exist with an ever greater number of co-pathologies as age-at-onset increases (8). The complexities of $A \beta$ oligomer research have been discussed in detail elsewhere (9). Some arguments will be emphasised here, but all are relevant to this area of AD research. Poor reproducibility between labs is often blamed on poorly-defined synthetic preparations loosely based on standard "recipes" rather than fully characterising the content of each batch produced. This common assumption can only be tested if all preparations are fully characterised when published $(9 ; 10)$. A recent trend towards defining toxic $A \beta$ assemblies by structural fingerprints, rather than the conditions in which they were produced, may help address this problem $(11 ; 12)$. As AD patient samples are both precious, and 
inherently complex and heterogeneous, it seems pragmatic to continue to test a hypothesis with synthetic or recombinant $A \beta$ that does not contain alternative APP metabolites before confirming the relevance with human samples (13). Indeed, $A \beta$ samples from $A D$ brain will always vary in composition, concentration and purity. Native isolation of different $A \beta$ assemblies present in $A D$ brain samples is complex, as purification methods can disrupt and change the conformation of aggregates (14). Identification of toxic receptors for such a heterologous disease will, of course, be challenging.

In receptor binding terminology, both receptor and acceptor contain a receptive site for the ligand, although only the receptor induces a biological function. Moreover, the acceptor lacks an endogenous ligand. Many proteins have been described as "receptors" for toxic A $\beta$ assemblies, implying a designed physiological function. It is possible that toxicity is linked to hijacking of a functional interaction with other $A \beta$ assemblies, but until this is demonstrated the candidates are best described as "acceptors" for toxic $A \beta$ assemblies. To date, the majority of research on the $\operatorname{PrP}: A \beta$ interaction has focused on the toxic signalling cascades rather than physiological or beneficial roles. Two possible functions of PrP as an A $\beta$ receptor have been suggested: Firstly, as a facilitator of the low-density lipoprotein (LDL) - receptor-related protein-1 (LRP1) mediated A $\beta$ monomer transcytosis out of the brain through the blood-brain barrier (BBB). Secondly, as a protector against $A \beta$-induced cell death by neutralising oligomeric $A \beta$ (15-19). If the $A \beta$ :PrP interaction has a function, it will no doubt unravel as we better understand the true physiological role of $\operatorname{PrP}(20)$. More research is needed to confirm the consequences of $A \beta$ assemblies binding to $\operatorname{Pr} P$, as this will be crucial to develop new therapies targeting the interaction or its downstream effectors.

\section{Prion protein-mediated $A \beta$ toxicity}

\section{The $A B$ oligomer as a ligand for prion protein}

Numerous macromolecules have been identified to bind to different forms of $A \beta(9 ; 21 ; 22)-$ not surprising given the inherently sticky nature of this peptide in all forms from monomer through to amyloid plaques. A study by Lauren et al. (23) stood out because it used an unbiased cell-based 
screen of all murine neuronal proteins to identify those that bound to a relatively well-defined preparation of $A \beta$, based on the "Amyloid- $\beta$-derived diffusible ligand" (ADDL) protocol (2). The only "hit" was prion protein (PrP). Not only was the interaction confirmed to occur at low nanomolar concentrations, PrP-knockout was also shown to prevent the toxic effect of $A \beta$ in a measure of synaptic plasticity, long term potentiation (LTP). Incubation of nanomolar concentrations of $A \beta$ with wild-type murine brain slices inhibited LTP, whereas in PrP-null mice LTP remained intact. Ironically, after years of effort to find specific, high affinity ligands for $\operatorname{PrP}$, the interaction of $\operatorname{PrP}$ with $A \beta$ was discovered from the opposite vantage point. Indeed, $A \beta$ is perhaps the most widely-accepted highaffinity binding partner for PrP.

\section{Confirming PrP-dependent toxicity in vivo}

A further study by the same group showed crossing a transgenic mouse model of AD that combines expression of mutant APP $_{\text {swe }}$ and presenilin-1 deltaE9 (PS1 ${ }_{\triangle \mathrm{Eg}}$ ) (both from PrP promoters on a PrPnull background) prevented pathological phenotypes such as neuronal loss and premature death whilst maintaining spatial learning and memory (24). Furthermore, a two-week peripheral treatment of another APP/PS1 mouse model $\left(\mathrm{APP}_{\text {swe }} \mathrm{PS}_{\mathrm{M} 146 \mathrm{~L}}\right.$ both with Thy1 promoters) with the $6 \mathrm{D} 11$ antibody increased the synaptic density in the hippocampus and improved spatial memory in a radial arm maze (25).

\section{Controversy and confirmation}

\section{PrP-independent $A B$ toxicity}

Following the initial report (23), a number of groups published seemingly contradictory reports. The first paper to cast doubt on the role of $\operatorname{PrP}$ in $A \beta$ toxicity nevertheless confirmed a $\operatorname{PrP}: A \beta$ binding interaction (26). According to this study, $\operatorname{PrP}^{\mathrm{c}}$ is not required for $A \beta$-induced memory impairment in a novel object recognition test when synthetic $A \beta$ oligomers are injected into the brains of mice. That $\operatorname{PrP}$ is not critical to all $A \beta$ toxic readouts is not surprising and does not discount a role for this 
protein in $A D$. However, this paper highlights an important point that not all $A \beta$ toxicity is governed by $\operatorname{PrP}$, even when the preparations are known to contain assemblies capable of interacting with PrP. Since the report of $\operatorname{PrP}$ as an $A \beta$ oligomer acceptor, numerous other $A \beta$-interacting candidates have been suggested (see below). These have mainly been identified using a targeted approach rather than the unbiased binding screen used for $\operatorname{PrP}(23 ; 27-34)$. Only by comparing the candidates side-by-side in the same assays can they be compared for their $A \beta$ oligomer affinity and selectivity. Given that the PrP:A $\beta$ interaction was reported first and the tools to study it are widely available within the molecular neuroscience community, it is not surprising that this interaction was quickly validated. Still, to date, PrP remains by far the most validated $A \beta$ acceptor.

Two studies described PrP-independent pathological, behavioural and electrophysiological changes in the $\operatorname{APPPS1}^{+}\left(\mathrm{APP}_{\text {swe }} \mathrm{PS}_{\text {L166P }}\right.$ both with Thy1 promoters) (35) or J20 (APP swe/ind $_{\text {with }}$ PDGF- $\beta$ promoter) (36) transgenic models. Potential PrP-specific reasons for these differences include the fact that some, but not all, models express APP using the PrP promoter and that PrP and APP processing may be interrelated (37). The contrasting findings might also be the result of differences in the soluble $A \beta$ assemblies present at the ages tested compared to the APP/PS1 lines (APPPS1 ${ }^{+}$ mice were used at 2-4 months of age and $J 20$ mice were 6-8 months old). In support of this hypothesis, a later study in the APPPS1 ${ }^{+}$mice showed some PrP-dependent effects at 14 months when soluble $A \beta$ assemblies, including SDS-stable dimers, become abundant (38). Another well-

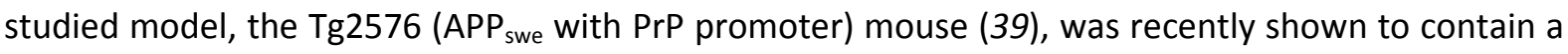
sub-population of PrP binding $A \beta$ assemblies and displayed a partial recovery of Morris Water Maze deficits when PrP was not expressed (40). It is known that J20 mice do not develop large pools of soluble $A \beta$ oligomers until 16 months of age (41) and it may be that PrP-dependent effects are observed at this age if they are not overwhelmed by pre-existing PrP-independent effects. In addition, J20-derived $A \beta$ oligomers are mainly recognised by the conformation-specific antibody $A 11$ (42) while $A \beta$ oligomers shown to bind $\operatorname{PrP}(43)$ contain in-register parallel $\beta$ sheets, recognised by the $O C$ antibody (44). It is not known which, if any, of these models better mimic $A \beta$ pathology in $A D$. 
However, confirmation of the involvement of specific proteins in human AD should help select more disease-relevant animal models that may in turn benefit $A D$ research and drug discovery. The corresponding authors of the first two papers reporting PrP-independent $A \beta$ toxicity $(26 ; 35)$ have since reported PrP-dependent effects in these models $(38 ; 45)$, suggesting that a consensus may be forming (Table 1).

One study directly contradicted the key finding of the original study (23) - that the inhibition of LTP by $A \beta$ oligomers was PrP-dependent. Kessels et al. produced $A \beta$ following the same protocol, but the inhibition of LTP appeared to be PrP-independent (46). In response Lauren et al. questioned the similarity of the $A \beta$ preparations that were only characterised by SDS-PAGE (47). Although SDS-PAGE has been shown to not reliably represent $A \beta$ assemblies present in solution (10), the contradictory studies highlight one problem with studies using synthetic preparations: how do we determine which assemblies are most relevant to the human condition?

\section{Independent confirmation of PrP-dependent toxicity}

It was crucial to discover whether synthetic $A \beta$ oligomers could be produced that mimicked the most disease relevant forms of $A \beta$ - those found in the brains of human AD patients that are known to inhibit LTP (48). Like some synthetic A $\beta$ oligomers, those purified from AD brain inhibited LTP in wildtype and not PrP-null mice, confirming some relevance to human AD (49). Surprisingly, a range of antibodies that bind close to helix-1 of PrP also effectively blocked the interaction, even though it is located on the opposite side of the structured domain of $\operatorname{PrP}^{C}$ from residue 95-105 (Figure 2). Antibodies that bind to 95-105 and helix-1 of PrP, and which are known to be therapeutically active in prion infection (50), were found to block $A \beta$-induced inhibition of LTP in both murine brain slices and live rats $(49 ; 51)$. The ability of helix-1 antibodies to block $A \beta$-induced electrophysiological deficits has now been replicated in a cell-based system (52). Previously discovered PrP ligands should now be retested for their ability to disrupt the $\operatorname{PrP}: A \beta$ interaction and their potential as $A D$ therapeutics assessed. Indeed, it may be that the identification of the PrP:A $\beta$ interaction may 
reinvigorate studies to identify small molecules that bind to $\operatorname{PrP}^{C}$ and arrest prion propagation (53). This is firstly because of the increased interest in PrP-binding molecules as possible inhibitors of $A \beta$ and, secondly, from a practical point-of-view, because it is challenging to identify PrP-binding molecules in high-throughput assays. Showing that a compound can block the PrP:A $\beta$ interaction appears to be an acceptable surrogate for identifying molecules that bind to certain sites on PrP (54).

\section{The A $\mathbf{P}:$ PrP interaction}

\section{Characterising the PrP binding mode}

The fact that there now appears to be a consensus on $A \beta$ :PrP binding does not mean it is a simple interaction; it should not be considered a canonical binary interaction between a PrP monomer and a discreet $A \beta$ oligomer. $A$ single oligomer has the potential to interact with multiple PrP molecules and this could result in further conformational changes to either PrP or A . Kinetic analysis confirmed that the interaction is effectively irreversible on a surface meaning dissociation constants cannot be calculated (55), whilst the slow rate of binding observed may be indicative of a conformational change or further $A \beta$ aggregation in situ (55). The mechanism for helix-1 antibodymediated inhibition of synaptotoxicity remains obscure (49), but hints towards the involvement of multiple PrP molecules (49) or a rearrangement of this helix during binding (53). A number of groups have suggested a second positively-charged site at the extreme $\mathrm{N}$-terminus of $\operatorname{PrP}(45 ; 55)$, but it is unclear if this is truly independent or what its relevance is at pathophysiologically pertinent concentration. The basis of the interaction has so far not been resolved at a single amino acid level (45). That PrP can disassemble $A \beta$ amyloid fibrils (56) and inhibit the assembly of $A \beta$ into toxic oligomeric forms (57) at micromolar concentrations confirms the interaction, whilst selective, is not specific at higher concentrations.

Identifying PrP-binding AB assemblies 
It is known that $\operatorname{PrP}$ does not bind as strongly to $A \beta$ monomer or mature fibrils $(26 ; 55)$, but numerous synthetic $A \beta$ assemblies have been reported (Figure 1) (9), some of which may only vary in their means of preparation rather than their actual composition. Aggregation of ADDL-like preparations for different time periods and then characterising the $A \beta$ assemblies present at different time points allowed the identification of forms that most avidly bind to PrP, as well as those that cause PrP-dependent or PrP-independent synaptotoxicity (43). The presence of A $\beta$ protofibrils correlated better with PrP binding than either globular oligomers or amyloid fibrils. Crucially, globular oligomers present at initial time points failed to inhibit LTP, whereas LTP was significantly reduced throughout a time window where protofibrils were present. The protofibrils are not simply chains of globular oligomers, but contain a defined triple helical nanotube structure that could relate to their specific PrP-dependent toxicity (Figure 3). Could the A $\beta$ species in AD brain that cause PrP-dependent toxicity be structurally related to $A \beta$ nanotubes? The presence of SDS-stable dimers in post-mortem brain is strongly associated with AD (3) and PrP-dependent toxicity in mice (38), whilst synthetic $A \beta$ dimers are known to favour synaptotoxic protofibril formation (58). Therefore, it seems plausible that structures similar to $A \beta$ nanotubes can cause PrP-dependent synaptotoxicity in $A D$ brain; although this hypothesis is yet to be tested experimentally. Several studies have, however, compared the PrP binding of different $A D$ brain-derived $A \beta$ species, separated by the hydrodynamic radii using size-exclusion chromatography, but none have confirmed if these species are toxic. Two independent studies have suggested large soluble assemblies with apparent molecular weights greater than 600,000 are the major PrP binding species $(40 ; 59 ; 60)$, with a third suggesting SDS-stable dimers are the major PrP binding species (38). All this is consistent with a protofibrillar assembly, although this will remain speculation until such species are isolated from AD brain, structurally characterised and shown to cause PrP-dependent toxicity.

\section{PrP-dependent toxic mechanisms}


Clearly not all A $\beta$ toxicity is governed by $\operatorname{PrP}$ (Table 1 ) and assemblies can display distinct toxicities in different systems; for example, inhibition of LTP compared with cell membrane disruption (43). Furthermore, a variety of non-mammalian protein aggregates induce PrP-dependent cytotoxicity in cellular systems (61). Toxicity is mediated through the unstructured $\mathrm{N}$-terminal portion of $\operatorname{PrP}$ suggesting some mechanistic overlap with toxic PrP and $A \beta$ species. Such toxicity, caused by interactions with the N-terminus of PrP, yet blocked by ligands binding to the 95-105 or helix-1 regions of PrP, is in contrast to reports of anti-PrP antibody-related toxicity caused by interaction with C-terminal regions of PrP and prevented by ligands binding the $\mathrm{N}$-terminus (62). The apparent mechanistic differences between $A \beta$-induced and anti-PrP antibody-induced toxicity could be explained by the method of incubation. Anti-PrP antibody toxicity was reported after their incubation with brain slices prepared from transgenic mice with a high level of PrP expression for several weeks at high, micromolar concentrations $-\sim 10,000$ times those required to engage PrP suggesting there may be non-specific toxic effects. This effect also appears inconsistent with absence of toxicity seen in vivo when up to two micrograms of multiple anti-PrP antibodies are directly injected into the hippocampi of live mice (63). Subsequent titration to 6 micrograms of PrP mAbs (64), injected directly into brain tissue (estimated volume of distribution $5 \mathrm{~mm}^{3}$ ), did however result in apoptosis at the cannula site. As for the brain slice experiments, dose and concentrations in these mouse experiments are high relative to those which might reasonably be expected to be therapeutically relevant. For example, Song et al. infused a PrP mAb at 1 microgram/hr into mouse lateral ventricle (estimated volume of distribution $500 \mathrm{~mm}^{3}$ ) with clinical benefits against prion disease and no adverse clinical or pathological events (65), implying an approximately two-log dose therapeutic window by comparison with Reimann et al.'s toxicity. Ohsawa et al. demonstrated some evidence of therapeutic potential for established mouse prion disease by peripheral injections of PrP mAb, with no adverse events (66). Klyubin et al. showed that intravascular injections of PrP mAb were able to block the effects of A $\beta$ on LTP without adverse events (67). This paper also reported the single ascending dose study of PrP mAb PRN100 in cynomolgus monkey at intravenous doses up to 
$200 \mathrm{mg} / \mathrm{kg}$, achieving serum concentrations of $5 \mathrm{mg} / \mathrm{ml}$ without significant adverse events (67).

Overall, these studies suggest that anti-PrP antibodies have a relatively low acute neurotoxicity at likely therapeutic concentrations for prion infection (65-67).

Whilst blocking the PrP:A $\beta$ interaction, or the formation of toxic assemblies, appear to be valid approaches to combatting $A \beta$ toxicity, it is also important to understand the cellular mechanisms and how they might be targeted pharmacologically. Identifying whether the binding of a specific $A \beta$ isoform to PrP inhibits a physiological function or triggers a dysfunctional pathway is crucial to drug discovery strategies.

PrP-dependent downstream mediators of toxicity

Phosphorylation of NMDA receptors and their subsequent relocalisation is induced by Fyn activation (30). Of all post-synaptic density membrane proteins tested, only mGluR5-dependent Fyn activation was increased by $A \beta$ oligomers (68). Formation of this complex may explain the observed clustering of mGluR5 at synapses in the presence of $A \beta$ oligomers $(68 ; 69)$. The role of mGluR5 in PrPdependent $A \beta$ toxicity has now been confirmed in the classic synaptic plasticity paradigm, inhibition of LTP, as well as in the associated facilitation of long-term depression (LTD) (70). It is possible that the PrP:mGluR5R interaction includes helix-1 of $\operatorname{PrP}(60)$ meaning that antibodies that bind helix-1 of PrP could disrupt this complex and have a secondary protective mechanism beyond directly inhibiting the PrP:A $\beta$ interaction. Such serendipity should perhaps be expected in the crowded environment of the synapse. The A :PrP:mGluR5 complex is probably the most studied and independently validated $A \beta: \operatorname{PrP}$ pathway and, importantly, its toxicity has been shown to be driven by $A D$ brain extracts $(30 ; 38 ; 68 ; 70)$. PrP is linked to Homer1b/c, protein-tyrosine kinase $2 \beta$ (PTK2B, Pyk2) and calcium/calmodulin-dependent protein Kinase II (CamKII) through mGluR5 in a A $\beta$ regulated manner (13) (71). In light of these results, it will be important to examine in more detail the physiological function of PrP:mGluR5 in order to assess the full toxic effect of $A \beta$ oligomers on 
synaptic plasticity. It is possible that as well as activating toxic cascades through $\operatorname{PrP}, A \beta$ oligomers also alter PrP:mGluR5 interactions crucial for a correct functioning of the synapse.

One effect of PrP may be to increase the local concentration of $A \beta$ or other protein aggregates (61) and initiate toxic pathways that it does not directly participate in. PrP could conceivably facilitate the conversion of other $A \beta$ assemblies into those that cause PrP-dependent toxicity (56). Likewise antiPrP antibodies could sterically block interactions with other $A \beta$-binding proteins closely packed within the synaptic membrane or block access of fibrillar $A \beta$ assemblies that do not exert toxicity through PrP. More targeted site-directed mutagenesis studies where the PrP:ligand interaction is retained yet toxicities are specifically blocked will be required to distinguish between these possibilities.

\section{Other $A B$ acceptors}

AB toxicity through other interacting proteins

Numerous $A \beta$ oligomer binding proteins have since been identified $(72 ; 73)$ and most of them localise at the synapse, suggesting that binding of $A \beta$ assemblies may cause synaptic dysfunction at least in part by blocking their function. Of course many macromolecules have been shown to bind to some form of $A \beta$ including: GluN1 (69;74), GluR2 (75), $\alpha 7 n A c h R$ (76), RAGE (77), insulin receptor (78), p75 ${ }^{\text {NTR }}(79 ; 80), \beta_{2}$ ARs (81), Fz Wnt receptor (82), NL1 (83), reelin (84), GM1 ganglioside (85) and LRP1 (86).

Although only $\operatorname{PrP}$ was identified by an unbiased direct binding assay, two other $A \beta$ oligomer acceptors were recently identified using unbiased functional screening or expression approaches: FcyRIlb (31)(87) and PGRMC1 (32;33) (88). A oligomers also bind EphB2 (27;29)(89). As Eph receptors regulate plasticity and synaptic function, it would not be surprising if more members of the family are involved in $A D(90)$. PirB and its human orthologue were also reported as possible $A \beta$ oligomer acceptors (28). Finally, NAKa3 binds to patient-derived amylospheroids (34). Detailed 
discussion of these receptors falls outside the bounds of this review. The heterogeneity in the properties of this small group of recently identified candidates highlights the difficulty in reproducing experiments between labs. Simply acquiring the expertise and reagents required to study one of these proteins and reproducing published experiments could take as long as a standard PhD project. Prioritising which of these acceptors is most relevant for slowing the progress of heterogeneous diseases such as Alzheimer's will be an enormous challenge.

Why might so many receptors be involved in a single disease? Of course there will no doubt be "false positives", but it is also likely that certain acceptors cause toxicity at different stages presymptomatic, mild cognitive impairment, early and more advanced $A D$ - as the different aggregates of $A \beta$ accumulate and form in the brain. It is crucial to characterise the $A \beta$ assemblies that bind each protein and their apparent affinity, together with any overlap in the downstream cascade they activate.

Synaptic loss occurs at early stages in $A D$, therefore protecting, maintaining and restoring the structure of the synapse could be central to AD therapy $(90 ; 91)$. Several neurotoxic cascades that are triggered by $A \beta: P r P$ in complex with other proteins, including LRP1, cytoplasmic phospholipase $A_{2}\left(C_{P L A}\right)$ and mGluR5, have been described to require lipid rafts organisation $(5 ; 30 ; 92 ; 93)$. Interestingly, these results agree with a suggested function for $\operatorname{PrP}$ as a scaffold protein on lipid rafts: organising proteins in a complex (94). Therefore, finding the scaffold proteins and necessary partners for the different receptors could identify relevant targets to develop therapies. A real challenge of targeting the above receptors is that complete inhibition of a receptor could be detrimental; therefore modulating their function back to physiological levels may be essential.

\section{Future Focus}

After initial scepticism and controversy the PrP:A interaction is now becoming accepted as a significant player in $A \beta$-mediated toxicity in vitro and in vivo. Its high affinity has not been disputed and the molecular basis of this complex interaction is now being unravelled. Care needs to be taken 
to ensure experiments are carried out under the most physiological conditions possible and are described in such a way that they can be faithfully reproduced. More details of the structural basis of the interaction and mechanisms of neurotoxicity, and concrete explanations for reported discrepancies between publications, are required to truly understand the phenomenon. It would aid the field if researchers reported both positive and negative results together to help establish the reasons for PrP-dependent and PrP-independent toxicity. If the hypothesis that PrP is involved in AD cannot be falsified then experimental medicine studies could be considered. The relevance of this interaction to the clinical features and progression of human $A D$ can only be firmly established through clinical trials of drug candidates that block the interaction or down-stream toxicity. This in turn could determine the suitability of individual animal models to AD drug discovery. A humanised anti-PrP monoclonal antibody has now been developed for treatment of prion disease and a preclinical study in live rats demonstrated that intravascular administration of this antibody can block $A \beta$-induced inhibition of synaptic plasticity without causing acute toxicity (67), suggesting it might be suitable for clinical trials in $A D$ should it have a satisfactory safety profile. Likewise, a phase 1b study for a potent inhibitor of src family of kinases, including Fyn, has recently been completed $(95 ; 96)$ with a phase Ila trial currently underway. Confirmation of efficacy in human trials would firmly establish a role for $\operatorname{PrP}^{C}$ in $A D$. It is unlikely that any therapeutic would reverse all symptoms in $A D$ patients, but blocking acute synaptotoxic effects may have an immediate measurable effect in memory and cognitive function. The second question of whether this then slowed rates of neurodegeneration would require major clinical trials. A confirmed disease-modifying therapeutic in the $A D$ field would be a huge step forward after so many disappointments. While the PrP:A $\beta$ interaction was only identified a few years ago, direct examination of its true relevance to $A D$ via experimental medicine may hopefully not be too far away.

\section{Financial disclosures}


SAP declares no conflict of interests. AJN is an employee of the Chemistry and Life Sciences Group at Elkington + Fife LLP, a firm of UK and European patent and trademark attorneys. JC is a Director and shareholder of D-Gen Limited, an academic spin-out company working in the field of prion disease diagnosis, decontamination and therapeutics. JC is an inventor of patents on the use of $\operatorname{PrP}$ antibodies for prion and AD therapeutics.

\section{Acknowledgments}

We thank Richard Newton for preparation of figures and Dr Simon Mead for critical review of the manuscript. This work was funded by the UK Medical Research Council. 


\section{Figure legends:}

Figure 1: Diagram depicting the variety of aggregation states of $A \beta$ and sizes. Green lines represent bands in gels, orange structures represent those captured by Atomic Force Microscopy (AFM) and black structures represent those captured by Electron Microscopy (EM). The y-axis identifies the name of the preparation and, where relevant identifies the source. ADDLs are "amyloid- $\beta$-derived diffusible ligand", TABFOs are "amyloid- $\beta_{1-42}$ fibrillar oligomers".

Figure 2: Modelled structure of $\operatorname{PrP}^{C}$ highlighting the $A \beta$ binding site (red) and Helix-1 (yellow). Amino acids in the region 95-105 are required for the interaction and antibodies raised against these epitopes (red and yellow) block the toxic effect of $A \beta$ oligomers on LTP.

Figure 3: Possible $\operatorname{PrP}^{C}$-dependent (left) and $\operatorname{PrP}^{C}$-independent pathways (right) for $A \beta$ toxicity as well as possible functional roles for $\operatorname{PrP}^{C}$ in $A \beta$ processing, signalling and transport (centre). $A \beta$ species, such as $A \beta$ nanotubes, are known to bind directly to $\operatorname{PrP}^{C}$ and induce toxicity and several, possibly interconnected, pathways have been identified. The $\operatorname{PrP}^{C}: A \beta$ complex may directly interact with downstream acceptors or $\operatorname{PrP}^{C}$ may raise the local concentrations of certain forms of $A \beta$ thereby sensitising acceptors to $A \beta$ toxicity. 


\begin{tabular}{|c|c|c|c|c|c|}
\hline \multirow[b]{2}{*}{ Reference } & \multicolumn{2}{|c|}{ Direct $A \beta: \operatorname{PrP}^{C}$ interaction } & \multicolumn{2}{|c|}{$A \beta: P r P^{C}$ toxicity } & \multirow[b]{2}{*}{ Comment } \\
\hline & $A \beta$ source & Quantitative & $A \beta$ source & $\begin{array}{l}\text { System } \\
\text { assayed }\end{array}$ & \\
\hline $\begin{array}{l}\text { Lauren et al. } \\
\qquad(23)\end{array}$ & Synth & Y & Synth & Cell & $\begin{array}{l}\text { A } \beta: P r P^{C} \text { binding in cells and effect on } \\
\text { LTP is } \operatorname{Pr}^{C} \text {-dependent }\end{array}$ \\
\hline $\begin{array}{l}\text { Balducci et } \\
\text { al. (26) }\end{array}$ & Synth & $\mathrm{N}$ & Synth & $\begin{array}{l}\text { Cell, Mouse } \\
\text { in vivo }\end{array}$ & Direct $A \beta: \operatorname{PrP}^{C}$ binding, but no toxicity \\
\hline $\begin{array}{l}\text { Gimbel et al. } \\
\qquad(24)\end{array}$ & & & Mouse & $\begin{array}{l}\text { Mouse in } \\
\text { vivo }\end{array}$ & $\begin{array}{l}\text { Ablation of } \operatorname{PrP}^{C} \text { reverses cognitive } \\
\text { deficits, lifetime and cell death in } \\
\mathrm{APP}_{\text {swe }} / \mathrm{PS}_{\triangle E \mathrm{~g}} \text { mouse }\end{array}$ \\
\hline $\begin{array}{l}\text { Chen et al. } \\
\quad(55)\end{array}$ & Synth & $\mathrm{N}$ & & & $\begin{array}{l}\text { Confirmation of direct binding of } A \beta \\
\text { oligomers to huPrPC }\end{array}$ \\
\hline $\begin{array}{l}\text { Calella et al. } \\
\qquad(35)\end{array}$ & Synth & $\mathrm{N}$ & Mouse & $\begin{array}{l}\text { Mouse in } \\
\text { vivo }\end{array}$ & $\begin{array}{l}\text { Confirmation of } A \beta: \operatorname{PrP}^{C} \text { interaction, but } \\
\text { disputes } \operatorname{PrP}^{C} \text {-dependent behavioural } \\
\text { effects in } A P P_{\text {swe }} / \operatorname{PS}_{L_{L 166 P}} \text { mouse }\end{array}$ \\
\hline $\begin{array}{l}\text { Kessels et al. } \\
\qquad(46)\end{array}$ & - & & Cell & $\begin{array}{l}\text { Mouse ex } \\
\text { vivo }\end{array}$ & $\begin{array}{l}\text { Disputes } \operatorname{PrP}^{\mathrm{C}} \text {-dependent } A \beta \text {-induced } \\
\text { LTP inhibition, however, uses ill-defined } \\
\text { A } \beta \text { oligomers }\end{array}$ \\
\hline $\begin{array}{l}\text { Lauren et al. } \\
\quad(47)\end{array}$ & & & & & Reply to Kessels et al. \\
\hline $\begin{array}{l}\text { Chung et al. } \\
\text { (25) }\end{array}$ & & & Mouse & $\begin{array}{l}\text { Mouse in } \\
\text { vivo }\end{array}$ & $\begin{array}{l}\text { Anti-PrP } m A b \text { reverses behavioural } \\
\text { effects in } A P P_{s w e} / P S 1_{\triangle E 9} \text { mouse }\end{array}$ \\
\hline $\begin{array}{l}\text { Resenberger } \\
\text { et al. (61) }\end{array}$ & Cell & $\mathrm{N}$ & & Cell & $\begin{array}{l}\text { PrP } \text {-dependent toxicity of } A \beta \text { and } \\
\text { amyloid peptides in cells }\end{array}$ \\
\hline $\begin{array}{l}\text { Zou et al. } \\
(100)\end{array}$ & $\begin{array}{l}\text { Mouse, } \\
\text { Human }\end{array}$ & $\mathrm{N}$ & & & $\begin{array}{l}A \beta \text { mainly interacts with insoluble } \operatorname{Pr} P^{C} \\
\text { in } A^{C} P_{\text {swe/ind }} \text { mice }\end{array}$ \\
\hline $\begin{array}{l}\text { Barry et al. } \\
\quad(51)\end{array}$ & & & Human & Rat in vivo & $\begin{array}{l}\text { Anti-PrPC } \mathrm{mAb} \text { reverses effect on } A D \\
\text { brain extract-induced LTP inhibition }\end{array}$ \\
\hline $\begin{array}{l}\text { Freir et al. } \\
\qquad(101)\end{array}$ & Synth & Y & $\begin{array}{l}\text { Synth, } \\
\text { Human }\end{array}$ & $\begin{array}{l}\text { Mouse ex } \\
\text { vivo, rat in } \\
\text { vivo }\end{array}$ & $\begin{array}{l}\text { Two anti-PrP } P^{C} \text { Abs reverse } A \beta \text {-induced } \\
\text { LTP defects in rats and mice }\end{array}$ \\
\hline $\begin{array}{l}\text { Cisse et al. } \\
\quad(36)\end{array}$ & & & Mouse & $\begin{array}{l}\text { Mouse in } \\
\text { vivo }\end{array}$ & $\begin{array}{l}\text { Disputes } \mathrm{PrP}^{\mathrm{C}} \text {-dependent } \\
\text { electrophysiological and lifetime effects } \\
\text { in } \mathrm{APP}_{\text {swe/ind }} \text { mice }\end{array}$ \\
\hline $\begin{array}{l}\text { Bate et al. } \\
\quad(93)\end{array}$ & Cell & $\mathrm{N}$ & Cell & Cell & $\begin{array}{l}\text { Initial report of } \operatorname{PrP}^{\mathrm{C}} \text {-dependence of } \\
\text { synapse damage via } \mathrm{CPLA}_{2}\end{array}$ \\
\hline $\begin{array}{l}\text { Alier et al. } \\
\quad(52)\end{array}$ & & & Synth & Cell & $\begin{array}{l}\text { PrP }{ }^{C} \text {-dependent electrophysiological } \\
\text { effects of } A \beta \text { in cells }\end{array}$ \\
\hline $\begin{array}{l}\text { Caetano et } \\
\text { al. (102) }\end{array}$ & Synth & $\mathrm{N}$ & Synth & Cell & $A \beta$ increases $\operatorname{Pr}^{C}$ at the cell surface \\
\hline $\begin{array}{l}\text { Kudo et al. } \\
\quad(103)\end{array}$ & & & Synth & $\begin{array}{l}\text { Mouse in } \\
\text { vivo }\end{array}$ & $\operatorname{PrP}^{\mathrm{C}}$-dependent neuronal death in vivo \\
\hline $\begin{array}{c}\text { You et al. } \\
(104)\end{array}$ & & & Synth & Cell & $\begin{array}{l}\text { Interaction between copper, } \operatorname{PrP}^{C}, A \beta \\
\text { oligomers and NMDAr }\end{array}$ \\
\hline $\begin{array}{c}\text { Pflanzner et } \\
\text { al. (15) }\end{array}$ & Synth & Y & Synth & Cell & $\begin{array}{l}\text { PrP } \mathrm{C}^{\mathrm{-}} \text {-dependent } \mathrm{A} \beta_{1-40} \text { transcytosis } \\
\text { across the } \mathrm{BBB}\end{array}$ \\
\hline $\begin{array}{l}\text { Guillot- } \\
\text { Sestier et al. } \\
(17)\end{array}$ & & & $\begin{array}{l}\text { Cell, } \\
\text { Human }\end{array}$ & Cell & $\begin{array}{l}\mathrm{N} 1 \text { fragment protects against } \mathrm{A} \beta \text { - } \\
\text { associated cell death }\end{array}$ \\
\hline $\begin{array}{l}\text { Hyeon et al. } \\
\text { (105) }\end{array}$ & Synth & $\mathrm{N}$ & Synth & Cell & PrP ${ }^{C}$-dependent apoptotic cell death \\
\hline
\end{tabular}




\begin{tabular}{|c|c|c|c|c|c|}
\hline $\begin{array}{l}\text { Um et al. } \\
(30)\end{array}$ & Human & $\mathrm{N}$ & $\begin{array}{l}\text { Synth, } \\
\text { Human }\end{array}$ & Cell & Fyn dependent toxicity via NMDAR \\
\hline $\begin{array}{l}\text { Rial et al. } \\
(106)\end{array}$ & & & Synth & $\begin{array}{l}\text { Mouse in } \\
\text { vivo }\end{array}$ & $\begin{array}{l}\text { Overexpression of } \operatorname{PrP}^{C} \text { protects against } \\
A \beta_{1-40} \text { apoptosis }\end{array}$ \\
\hline $\begin{array}{l}\text { Nieznanski } \\
\text { et al. (57) }\end{array}$ & Synth & $\mathrm{N}$ & & & $\begin{array}{l}\text { PrP } P^{C} N 1 \text { fragment inhibits } A \beta \text { oligomer } \\
\text { formation }\end{array}$ \\
\hline $\begin{array}{l}\text { Larson et al. } \\
\quad(38)\end{array}$ & Human & $\mathrm{N}$ & $\begin{array}{l}\text { Synth, } \\
\text { Human }\end{array}$ & $\begin{array}{l}\text { Cell, Mouse } \\
\text { in vivo }\end{array}$ & $\begin{array}{l}\text { Fyn dependent toxicity linked to Tau } \\
\text { phosphorylation }\end{array}$ \\
\hline $\begin{array}{l}\text { Younan et } \\
\text { al. (56) }\end{array}$ & Synth & Y & Synth & $\begin{array}{l}\text { Cell, Mouse } \\
\text { in vivo }\end{array}$ & $\begin{array}{l}\text { PrP } P^{C} \text { prevents aggregation and } \\
\text { disaggregates } A \beta \text { fibrils }\end{array}$ \\
\hline $\begin{array}{c}\text { Fluharty et } \\
\text { al. (45) }\end{array}$ & Synth & $\mathrm{N}$ & & & $\begin{array}{l}\text { PrPC } \text {-based peptides deactivate } A \beta \\
\text { oligomers }\end{array}$ \\
\hline $\begin{array}{l}\text { Rushworth } \\
\text { et al. (92) }\end{array}$ & Synth & $\mathrm{N}$ & Synth & Cell & $\begin{array}{l}\text { Role of lipid rafts and LRP-1 in PrPC } \\
\text { dependent } A \beta \text { toxicity }\end{array}$ \\
\hline $\begin{array}{l}\text { Ordonez- } \\
\text { Gutierrez et } \\
\text { al. (107) }\end{array}$ & & & Mouse & $\begin{array}{l}\text { Mouse in } \\
\text { vivo }\end{array}$ & $\begin{array}{l}\text { Confirmation of } \mathrm{PrP}^{\mathrm{C}} \text {-dependent } A \beta \\
\text { toxicity in } \mathrm{APP}_{\text {swe }} / \mathrm{PS}_{\triangle E 9} \text { mouse }\end{array}$ \\
\hline $\begin{array}{l}\text { Chen et al. } \\
(108)\end{array}$ & Synth & $\mathrm{N}$ & Synth & Cell & Confirmation of Fyn activation \\
\hline $\begin{array}{c}\text { Um et al. } \\
(68)\end{array}$ & $\begin{array}{l}\text { Synth, } \\
\text { Human }\end{array}$ & $\mathrm{N}$ & $\begin{array}{l}\text { Synth, } \\
\text { Human }\end{array}$ & $\begin{array}{l}\text { Cell, Mouse } \\
\text { in vivo }\end{array}$ & $\begin{array}{l}\text { mGluR5 as coupling receptor between } \\
\operatorname{PrP}^{C} \text { and Fyn }\end{array}$ \\
\hline $\begin{array}{l}\text { Nicoll et al. } \\
\quad(43)\end{array}$ & Synth & $\mathrm{N}$ & Synth & $\begin{array}{l}\text { Mouse ex } \\
\text { vivo }\end{array}$ & $\begin{array}{l}\text { A } \beta \text { nanotubes correlate with } \operatorname{PrP}^{C}- \\
\text { dependent inhibition of LTP }\end{array}$ \\
\hline $\begin{array}{l}\text { Ostapchenk } \\
\text { o et al. (109) }\end{array}$ & Synth & $\mathrm{N}$ & Synth & Cell & STI1 blocks $A \beta$ binding to PrP ${ }^{C}$ \\
\hline $\begin{array}{l}\text { Rubel et al. } \\
(110)\end{array}$ & Synth & $\mathrm{N}$ & & & $\begin{array}{l}\text { Confirmation of main binding site for } \\
\text { the interaction } A \beta: P r P^{C}\end{array}$ \\
\hline $\begin{array}{l}\text { An et al. } \\
(111)\end{array}$ & Synth & $\mathrm{N}$ & $\begin{array}{l}\text { Synth, } \\
\text { Human }\end{array}$ & Rat in vivo & Role of exosomes \\
\hline $\begin{array}{l}\text { Nah et al. } \\
(112)\end{array}$ & & & Synth & Cell & $\begin{array}{l}\text { A } \beta \text {-induced autophagy mediated by } \\
\text { presence of PrPC }\end{array}$ \\
\hline $\begin{array}{l}\text { Rushworth } \\
\text { et al. (113) }\end{array}$ & $\begin{array}{l}\text { Synth, } \\
\text { Cell }\end{array}$ & Y & & & Fragment of $\mathrm{PrP}^{\mathrm{C}}$ used as biosensor \\
\hline $\begin{array}{l}\text { Dohler et al. } \\
\text { (59) }\end{array}$ & $\begin{array}{l}\text { Synth, } \\
\text { Human }\end{array}$ & $\mathrm{N}$ & & & $\begin{array}{l}\operatorname{PrP}^{\mathrm{C}} \text { binds to large } A \beta \text { species in } A D \\
\text { brain }\end{array}$ \\
\hline Hu et al. (70) & & & $\begin{array}{l}\text { Synth, } \\
\text { Human }\end{array}$ & Rat in vivo & $\begin{array}{l}\text { PrP }{ }^{C}: m G l u R 5 \text { in A } \beta \text {-induced LTD } \\
\text { facilitation and LTP inhibition }\end{array}$ \\
\hline $\begin{array}{l}\text { Beland et al. } \\
\text { (16) }\end{array}$ & Human & $\mathrm{N}$ & Cell & Cell & $\begin{array}{l}\text { Secreted } \operatorname{Pr} P^{C} \text { trap } A \beta \text { in amorphous } \\
\text { aggregates }\end{array}$ \\
\hline $\begin{array}{l}\text { Klyubin et al. } \\
(67)\end{array}$ & Synth & Y & Human & Rat in vivo & $\begin{array}{l}\text { Intravascular administration of anti-PrP }{ }^{\mathrm{C}} \\
\text { antibody }\end{array}$ \\
\hline $\begin{array}{l}\text { Haas et al. } \\
(60)\end{array}$ & $\begin{array}{l}\text { Synth, } \\
\text { Mouse }\end{array}$ & $\mathrm{N}$ & & & $\begin{array}{l}\text { Confirmation of interaction between } \\
\operatorname{PrP}^{C} \text { and mGluR5 }\end{array}$ \\
\hline $\begin{array}{l}\text { Ganzinger et } \\
\text { al. (114) }\end{array}$ & Synth & Y & Synth & Cell & $\begin{array}{l}\text { Confirmation of } A \beta: P r P C \text { interaction by } \\
\text { single molecule imaging }\end{array}$ \\
\hline $\begin{array}{l}\text { Peters et al. } \\
\quad(115)\end{array}$ & Synth & $\mathrm{N}$ & Synth & Cell & $\begin{array}{l}\text { PrP }{ }^{\mathrm{C}} \text {-dependent membrane damage and } \\
\text { synaptotoxicity }\end{array}$ \\
\hline $\begin{array}{l}\text { West et al. } \\
\quad(116)\end{array}$ & Cell & $\mathrm{N}$ & Cell & Cell & $\begin{array}{l}\text { Monoacylated PrP }{ }^{C} \text { binds synaptotoxic } \\
A \beta \text { oligomers }\end{array}$ \\
\hline $\begin{array}{l}\text { Risse et al. } \\
\quad(54)\end{array}$ & Synth & $Y$ & & & $\begin{array}{l}\text { Disruption of } A \beta: \operatorname{PrP}^{C} \text { interaction by } \\
\text { small molecule. }\end{array}$ \\
\hline
\end{tabular}




\begin{tabular}{|c|c|c|c|c|c|}
\hline $\begin{array}{l}\text { Haas et al. } \\
\text { (13) }\end{array}$ & & & $\begin{array}{l}\text { Synth, } \\
\text { Human }\end{array}$ & $\begin{array}{l}\text { Mouse ex } \\
\text { vivo }\end{array}$ & $\begin{array}{l}\text { Downstream signalling cascade for } \\
A \beta: P r P^{C} \text { :mGluR5 }\end{array}$ \\
\hline $\begin{array}{l}\text { Falker et al. } \\
\text { (19) }\end{array}$ & Synth & $\mathrm{N}$ & Synth & Cell & Protective role of exosomes \\
\hline $\begin{array}{l}\text { Williams et } \\
\text { al. (117) }\end{array}$ & Synth & $\mathrm{N}$ & & & $\begin{array}{l}\operatorname{PrP}^{\mathrm{C}} \text { inhibits low molecular weight } \mathrm{A} \beta \\
\text { oligomers-induced toxicity }\end{array}$ \\
\hline $\begin{array}{l}\text { Kostylev et } \\
\text { al. (40) }\end{array}$ & $\begin{array}{l}\text { Mouse, } \\
\text { Human }\end{array}$ & Y & $\begin{array}{l}\text { Mouse, } \\
\text { Human }\end{array}$ & $\begin{array}{l}\text { Mouse in } \\
\text { vivo }\end{array}$ & $\begin{array}{l}\text { PrP }{ }^{C} \text { interacts with a pool of soluble } \\
\text { high molecular weight } A \beta \text { to induce } \\
\text { PrP }^{C} \text {-dependent cognitive defects }\end{array}$ \\
\hline $\begin{array}{l}\text { De Mario et } \\
\text { al. (118) }\end{array}$ & & & Synth & Cell & $\begin{array}{l}\text { Effect of } A \beta: P^{P} P^{C} \text { complex on store- } \\
\text { operated } \mathrm{Ca}^{+2} \text { entry via Fyn }\end{array}$ \\
\hline $\begin{array}{l}\text { Heiss et al. } \\
\text { (119) }\end{array}$ & Mouse & Y & Mouse & Mouse & $\begin{array}{l}\text { Reverses dendritic spine loss in } \\
\mathrm{APP}_{\text {swe }} / \mathrm{PS}_{\triangle E \mathrm{~g}} \text { mouse }\end{array}$ \\
\hline $\begin{array}{l}\text { Beraldo et } \\
\text { al. (120) }\end{array}$ & Synth & $\mathrm{N}$ & Synth & $\begin{array}{l}\text { Cell, Mouse } \\
\text { in vivo }\end{array}$ & $\begin{array}{l}\text { Possible role of } A \beta: P r P^{C}: m G l u R 5 \\
\text { complex }\end{array}$ \\
\hline $\begin{array}{l}\text { Pinnock et } \\
\text { al. (121) }\end{array}$ & Synth & $\mathrm{N}$ & Synth & Cell & $\begin{array}{l}\text { Reverses } A \beta: P r P^{C} \text { cytotoxicity by LRP/LR } \\
\text { antibody }\end{array}$ \\
\hline $\begin{array}{l}\text { Haas et al. } \\
\quad(71)\end{array}$ & & & Synth & $\begin{array}{c}\text { Mouse ex } \\
\text { vivo }\end{array}$ & $\begin{array}{l}\text { Effect of } A \beta: P r P^{C}: m G l u R 5 \text { complex on } \\
\text { glutamate signalling }\end{array}$ \\
\hline $\begin{array}{l}\text { Sempou et } \\
\text { al. (122) }\end{array}$ & & & Synth & Zebrafish & $\begin{array}{l}\text { Src family kinases activation in a } \\
A \beta: P r P^{C} \text {-dependent manner }\end{array}$ \\
\hline $\begin{array}{l}\text { Scott- } \\
\text { McKean et } \\
\text { al. (18) }\end{array}$ & & & Synth & $\begin{array}{l}\text { Cell, Mouse } \\
\text { ex vivo }\end{array}$ & $\begin{array}{l}\text { Reverses } A \beta \text {-induced synaptic plasticity } \\
\text { impairment by } \operatorname{Pr}^{C} \text { fragments }\end{array}$ \\
\hline $\begin{array}{l}\text { Haas et al. } \\
(123)\end{array}$ & & & Synth & Cell, Mouse & $\begin{array}{l}\text { Reverses AD mouse phenotypes by } \\
\text { mGluR5 selective blocker }\end{array}$ \\
\hline $\begin{array}{l}\text { Nolan et al. } \\
\quad(124)\end{array}$ & & & Cell & Cell & $\begin{array}{l}\text { Role of the glycosylphosphatidylinositol } \\
\text { (GPI) anchor attached to PrP }\end{array}$ \\
\hline $\begin{array}{l}\text { West et al. } \\
\quad(125)\end{array}$ & & & Human & Cell & $\begin{array}{l}\text { Cholesterol ester cycle regulates } \\
A \beta: \operatorname{PrP}^{C} \text { complex }\end{array}$ \\
\hline $\begin{array}{l}\text { Zhang et al. } \\
\quad(126)\end{array}$ & & & Synth, Rat & Rat in vivo & $\begin{array}{l}\text { Repetitive anti-PrP } \mathrm{P}^{\mathrm{C}} \text { antibody } \\
\text { administration reverses } \mathrm{A} \beta \text {-induced } \\
\text { synaptic plasticity defects on } \\
\text { longitudinal studies }\end{array}$ \\
\hline
\end{tabular}

Table 1: Summary of publications demonstrating a direct interaction between $\operatorname{PrP}^{c}$ and $A \beta$ (quantitative or not) specifying the source of $A B$ oligomers used and also those that reported PrP $\mathrm{P}^{\mathrm{c}}$ dependent toxicity (green) and $\operatorname{PrP}^{\mathrm{C}}$-independent toxicity (red), stating source of $A \beta$ oligomers and systems employed. Synth, synthetic. 
References

1. Selkoe DJ (2011): Alzheimer's disease. Cold Spring Harb Perspect Biol 3.

2. Lambert MP, Barlow AK, Chromy BA, Edwards C, Freed R, Liosatos M, et al (1998): Diffusible, nonfibrillar ligands derived from Abeta1-42 are potent central nervous system neurotoxins. Proc Natl Acad Sci U S A 95:6448-6453.

3. Mc Donald JM, Savva GM, Brayne C, Welzel AT, Forster G, Shankar GM, et al (2010): The presence of sodium dodecyl sulphate-stable Abeta dimers is strongly associated with Alzheimer-type dementia. Brain 133:1328-1341.

4. Lu JX, Qiang W, Yau WM, Schwieters CD, Meredith SC, Tycko R (2013): Molecular structure of beta-Amyloid fibrils in Alzheimer's disease brain tissue. Cell 154:1257-1268.

5. Watts JC, Condello C, Stohr J, Oehler A, Lee J, DeArmond SJ, et al (2014): Serial propagation of distinct strains of Abeta prions from Alzheimer's disease patients. Proc Natl Acad Sci U S A 111:10323-10328.

6. Walker LC, Schelle J, Jucker M (2016): The prion-like properties of Amyloid-beta assemblies: implications for Alzheimer's disease. Cold Spring Harb Perspect Med 6.

7. Collinge J (2016): Mammalian prions and their wider relevance in neurodegenerative diseases. Nature 539:217-226.

8. Selkoe DJ, Hardy J (2016): The amyloid hypothesis of Alzheimer's disease at 25 years. EMBO Mol Med 8:595-608.

9. Benilova I, Karran E, De Strooper B (2012): The toxic Abeta oligomer and Alzheimer's disease: an emperor in need of clothes. Nat Neurosci 15:349-357.

10. Hepler RW, Grimm KM, Nahas DD, Breese R, Dodson EC, Acton P, et al (2006): Solution state characterization of amyloid beta-derived diffusible ligands. Biochemistry 45:15157-15167.

11. Fawzi NL, Ying JF, Ghirlando R, Torchia DA, Clore GM (2011): Atomic-resolution dynamics on the surface of amyloid-beta protofibrils probed by solution NMR. Nature 480:268-272.

12. Stroud JC, Liu C, Teng PK, Eisenberg D (2012): Toxic fibrillar oligomers of amyloid-beta have cross-beta structure. Proc Natl Acad Sci USA 109:7717-7722.

13. Haas LT, Salazar SV, Kostylev MA, Um JW, Kaufman AC, Strittmatter SM (2015): Metabotropic glutamate receptor 5 couples cellular prion protein to intracellular signalling in Alzheimer's disease. Brain 139:526-546.

14. Esparza TJ, Wildburger NC, Jiang H, Gangolli M, Cairns NJ, Bateman RJ, et al (2016): Soluble Amyloid-beta aggregates from human Alzheimer's disease brains. Sci Rep 6:38187.

15. Pflanzner T, Petsch B, Andre-Dohmen B, Muller-Schiffmann A, Tschickardt S, Weggen S, et al (2012): Cellular prion protein participates in amyloid-beta transcytosis across the bloodbrain barrier. J Cereb Blood Flow Metab 32:628-632. 
16. Beland M, Bedard M, Tremblay G, Lavigne P, Roucou X (2014): A beta induces its own prion protein $\mathrm{N}$-terminal fragment (PrPN1)-mediated neutralization in amorphous aggregates. Neurobiol Aging 35:1537-1548.

17. Guillot-Sestier MV, Sunyach C, Ferreira ST, Marzolo MP, Bauer C, Thevenet A, et al (2012): alpha-secretase-derived fragment of cellular prion, $\mathrm{n} 1$, protects against monomeric and oligomeric Amyloid beta (Abeta)-associated cell death. J Biol Chem 287:5021-5032.

18. Scott-McKean JJ, Surewicz K, Choi JK, Ruffin VA, Salameh Al, Nieznanski K, et al (2016): Soluble prion protein and its $\mathrm{N}$-terminal fragment prevent impairment of synaptic plasticity by Abeta oligomers: Implications for novel therapeutic strategy in Alzheimer's disease. Neurobiol Dis 91:124-131.

19. Falker C, Hartmann A, Guett I, Dohler F, Altmeppen H, Betzel C, et al (2015): Exosomal PrP drives fibrillization of amyloid beta and counteracts amyloid beta-mediated neurotoxicity. $J$ Neurochem 137:88-100.

20. Kuffer A, Lakkaraju AK, Mogha A, Petersen SC, Airich K, Doucerain C, et al (2016): The prion protein is an agonistic ligand of the G protein-coupled receptor Adgrg6. Nature 536:464-468.

21. Benilova I, De Strooper B (2013): Promiscuous Alzheimer's amyloid: yet another partner. Science 341:1354-1355.

22. Jarosz-Griffiths HH, Noble E, Rushworth JV, Hooper NM (2015): Amyloid-beta receptors: the good, the bad and the prion protein. J Biol chem 291:3174-3183.

23. Lauren J, Gimbel DA, Nygaard HB, Gilbert JW, Strittmatter SM (2009): Cellular prion protein mediates impairment of synaptic plasticity by amyloid-beta oligomers. Nature 457:11281132.

24. Gimbel DA, Nygaard HB, Coffey EE, Gunther EC, Lauren J, Gimbel ZA, et al (2010): Memory impairment in transgenic Alzheimer mice requires cellular prion protein. J Neurosci 30:63676374.

25. Chung E, Ji Y, Sun Y, Kascsak RJ, Kascsak RB, Mehta PD, et al (2010): Anti-PrP $P^{C}$ monoclonal antibody infusion as a novel treatment for cognitive deficits in an Alzheimer's disease model mouse. BMC Neurosci 11:130.

26. Balducci C, Beeg M, Stravalaci M, Bastone A, Sclip A, Biasini E, et al (2010): Synthetic amyloid-beta oligomers impair long-term memory independently of cellular prion protein. Proc Natl Acad Sci USA 107:2295-2300.

27. Lacor PN, Buniel MC, Furlow PW, Clemente AS, Velasco PT, Wood M, et al (2007): Abeta oligomer-induced aberrations in synapse composition, shape, and density provide a molecular basis for loss of connectivity in Alzheimer's disease. J Neurosci 27:796-807.

28. Kim T, Vidal GS, Djurisic M, William CM, Birnbaum ME, Garcia KC, et al (2013): Human LilrB2 is a beta-Amyloid receptor and its murine homolog PirB regulates synaptic plasticity in an Alzheimer's model. Science 341:1399-1404.

29. Cisse M, Halabisky B, Harris J, Devidze N, Dubal DB, Sun BG, et al (2011): Reversing EphB2 depletion rescues cognitive functions in Alzheimer model. Nature 469:47-52. 
30. Um JW, Nygaard HB, Heiss JK, Kostylev MA, Stagi M, Vortmeyer A, et al (2012): Alzheimer amyloid-beta oligomer bound to postsynaptic prion protein activates Fyn to impair neurons. Nat Neurosci 15:1227-1235.

31. Kam TI, Song S, Gwon Y, Park H, Yan JJ, Im I, et al (2013): Fc gamma Rllb mediates amyloidbeta neurotoxicity and memory impairment in Alzheimer's disease. J Clin Invest 123:27912802.

32. Izzo NJ, Xu J, Zeng C, Kirk MJ, Mozzoni K, Silky C, et al (2014): Alzheimer's therapeutics targeting amyloid beta 1-42 oligomers II: Sigma-2/PGRMC1 receptors mediate Abeta 42 oligomer binding and synaptotoxicity. PLOS ONE 9:e111899.

33. Izzo NJ, Staniszewski A, To L, Fa M, Teich AF, Saeed F, et al (2014): Alzheimer's therapeutics targeting amyloid beta 1-42 oligomers I: Abeta 42 oligomer binding to specific neuronal receptors is displaced by drug candidates that improve cognitive deficits. PLOS ONE 9:e111898.

34. Ohnishi T, Yanazawa M, Sasahara T, Kitamura Y, Hiroaki H, Fukazawa Y, et al (2015): Na, KATPase alpha3 is a death target of Alzheimer patient amyloid-beta assembly. Proc Natl Acad Sci U S A 112:E4465-E4474.

35. Calella AM, Farinelli M, Nuvolone M, Mirante O, Moos R, Falsig J, et al (2010): Prion protein and Abeta-related synaptic toxicity impairment. EMBO Mol Med 2:306-314.

36. Cisse M, Sanchez PE, Kim DH, Ho K, Yu GQ, Mucke L (2011): Ablation of cellular prion protein does not ameliorate abnormal neural network activity or cognitive dysfunction in the J20 line of human amyloid precursor protein transgenic mice. J Neurosci 31:10427-10431.

37. Griffiths HH, Whitehouse IJ, Baybutt H, Brown D, Kellett KA, Jackson CD, et al (2011): Prion protein interacts with BACE1 protein and differentially regulates its activity toward wild type and Swedish mutant amyloid precursor protein. J Biol Chem 286:33489-33500.

38. Larson M, Sherman MA, Amar F, Nuvolone M, Schneider JA, Bennett DA, et al (2012): The complex $\operatorname{PrP}^{\mathrm{C}}$-Fyn couples human oligomeric Abeta with pathological Tau changes in Alzheimer's disease. J Neurosci 32:16857-16871.

39. Hsiao K, Chapman P, Nilsen S, Eckman C, Harigaya Y, Younkin S, et al (1996): Correlative memory deficits, A beta elevation, and amyloid plaques in transgenic mice. Science 274:99102.

40. Kostylev MA, Kaufman AC, Nygaard HB, Patel P, Haas LT, Gunther EC, et al (2015): PrionProtein-interacting Amyloid-beta oligomers of high molecular weight are tightly correlated with memory impairment in multiple Alzheimer mouse models. J Biol Chem 290:1741517438 .

41. Shankar GM, Leissring MA, Adame A, Sun XY, Spooner E, Masliah E, et al (2009): Biochemical and immunohistochemical analysis of an Alzheimer's disease mouse model reveals the presence of multiple cerebral Abeta assembly forms throughout life. Neurobiol Dis 36:293302.

42. Liu P, Reed MN, Kotilinek LA, Grant MK, Forster CL, Qiang W, et al (2015): Quaternary structure defines a large class of Amyloid-beta oligomers neutralized by sequestration. Cell Rep 11:1760-1771. 
43. Nicoll AJ, Panico S, Freir DB, Wright D, Terry C, Risse E, et al (2013): Amyloid-beta nanotubes are associated with prion protein-dependent synaptotoxicity. Nat Commun 4:2416.

44. Kayed R, Head E, Sarsoza F, Saing T, Cotman CW, Necula M, et al (2007): Fibril specific, conformation dependent antibodies recognize a generic epitope common to amyloid fibrils and fibrillar oligomers that is absent in prefibrillar oligomers. Mol Neurodegener 2:18.

45. Fluharty BR, Biasini E, Stravalaci M, Sclip A, Diomede L, Balducci C, et al (2013): An Nterminal fragment of the prion protein binds to amyloid-beta oligomers and inhibits their neurotoxicity in vivo. J Biol Chem 288:7857-7866.

46. Kessels HW, Nguyen LN, Nabavi S, Malinow R (2010): The prion protein as a receptor for amyloid-beta. Nature 466:E3-E4.

47. Lauren J, Gimbel DA, Nygaard HB, Gilbert JW, Strittmatter SM (2010): Lauren et al. reply. Nature 466:E4-E5.

48. Shankar GM, Li S, Mehta TH, Garcia-Munoz A, Shepardson NE, Smith I, et al (2008): Amyloidbeta protein dimers isolated directly from Alzheimer's brains impair synaptic plasticity and memory. Nat Med 14:837-842.

49. Freir DB, Nicoll AJ, Klyubin I, Panico S, Mc Donald JM, Risse E, et al (2011): Interaction between prion protein and toxic amyloid beta assemblies can be therapeutically targeted at multiple sites. Nat Commun 2:336.

50. Antonyuk SV, Trevitt CR, Strange RW, Jackson GS, Sangar D, Batchelor M, et al (2009): Crystal structure of human prion protein bound to a therapeutic antibody. Proc Natl Acad Sci USA 106:2554-2558.

51. Barry AE, Klyubin I, Mc Donald JM, Mably AJ, Farrell MA, Scott M, et al (2011): Alzheimer's disease brain-derived amyloid-beta-mediated inhibition of LTP in vivo is prevented by immunotargeting cellular prion protein. J Neurosci 31:7259-7263.

52. Alier K, Ma L, Yang J, Westaway D, Jhamandas JH (2011): Abeta inhibition of ionic conductance in mouse basal forebrain neurons is dependent upon the cellular prion protein PrP ${ }^{C}$. J Neurosci 31:16292-16297.

53. Nicoll AJ, Collinge J (2009): Preventing prion pathogenicity by targeting the cellular prion protein. Infect Disord Drug Targets 9:48-57.

54. Risse E, Nicoll AJ, Taylor WA, Wright D, Badoni M, Yang X, et al (2015): Identification of a compound which disrupts binding of amyloid-beta to the prion protein using a novel fluorescence-based assay. J Biol Chem 290:17020-17028.

55. Chen S, Yadav SP, Surewicz WK (2010): Interaction between human prion protein and amyloid-beta (Abeta) oligomers: role of N-terminal residues. J Biol Chem 285:26377-26383.

56. Younan ND, Sarell CJ, Davies P, Brown DR, Viles JH (2013): The cellular prion protein traps Alzheimer's Abeta in an oligomeric form and disassembles amyloid fibers. FASEB J 27:18471858.

57. Nieznanski K, Choi JK, Chen S, Surewicz K, Surewicz WK (2012): Soluble Prion Protein Inhibits Amyloid-ß (Aß) Fibrillization and Toxicity. J Biol Chem 287:33104-33108. 
58. O'Nuallain B, Freir DB, Nicoll AJ, Risse E, Ferguson N, Herron CE, et al (2010): Amyloid \{beta\}protein dimers rapidly form stable synaptotoxic protofibrils. J Neurosci 30:14411-14419.

59. Dohler F, Sepulveda-Falla D, Krasemann S, Altmeppen H, Schluter H, Hildebrand D, et al (2014): High molecular mass assemblies of amyloid-beta oligomers bind prion protein in patients with Alzheimer's disease. Brain 137:873-886.

60. Haas LT, Kostylev MA, Strittmatter SM (2014): Therapeutic molecules and endogenous ligands regulate the interaction between brain cellular prion protein $\left(\operatorname{PrP}^{\mathrm{C}}\right)$ and metabotropic glutamate receptor 5 (mGluR5). J Biol Chem 289:28460-28477.

61. Resenberger UK, Harmeier A, Woerner AC, Goodman JL, Muller V, Krishnan R, et al (2011): The cellular prion protein mediates neurotoxic signalling of beta-sheet-rich conformers independent of prion replication. EMBO J 30:2057-2070.

62. Sonati T, Reimann RR, Falsig J, Baral PK, O'Connor T, Hornemann S, et al (2013): The toxicity of antiprion antibodies is mediated by the flexible tail of the prion protein. Nature 501:102106.

63. Klohn PC, Farmer M, Linehan JM, O'Malley C, de Marco MF, Taylor W, et al (2012): PrP antibodies do not trigger mouse hippocampal neuron apoptosis. Science 335:52.

64. Reimann RR, Sonati T, Hornemann S, Herrmann US, Arand M, Hawke S, et al (2016): Differential toxicity of antibodies to the prion protein. PLoS Pathog 12:e1005401.

65. Song $\mathrm{CH}$, Furuoka $\mathrm{H}$, Kim CL, Ogino $\mathrm{M}$, Suzuki $\mathrm{A}$, Hasebe $\mathrm{R}$, et al (2008): Effect of intraventricular infusion of anti-prion protein monoclonal antibodies on disease progression in prion-infected mice. J Gen Virol 89:1533-1544.

66. Ohsawa N, Song CH, Suzuki A, Furuoka H, Hasebe R, Horiuchi M (2013): Therapeutic effect of peripheral administration of an anti-prion protein antibody on mice infected with prions. Microbiol Immunol 57:288-297.

67. Klyubin I, Nicoll AJ, Khalili-Shirazi A, Farmer M, Canning S, Mably A, et al (2014): Peripheral administration of a humanized anti-PrP antibody blocks Alzheimer's disease Abeta synaptotoxicity. J Neurosci 34:6140-6145.

68. Um JW, Kaufman AC, Kostylev M, Heiss JK, Stagi M, Takahashi H, et al (2013): Metabotropic glutamate receptor 5 is a coreceptor for Alzheimer abeta oligomer bound to cellular prion protein. Neuron 79:887-902.

69. Renner M, Lacor PN, Velasco PT, Xu JA, Contractor A, Klein WL, et al (2010): Deleterious Effects of Amyloid beta Oligomers Acting as an Extracellular Scaffold for mGluR5. Neuron 66:739-754.

70. Hu NW, Nicoll AJ, Zhang D, Mably AJ, O'Malley T, Purro SA, et al (2014): mGlu5 receptors and cellular prion protein mediate amyloid- $\beta$-facilitated synaptic long-term depression in vivo. Nat Commun 5:3374.

71. Haas LT, Strittmatter SM (2016): Oligomers of amyloid-beta prevent physiological activation of the cellular prion protein-metabotropic glutamate receptor 5 complex by glutamate in Alzheimer's disease. J Biol Chem 291:17112-17121. 
72. Xia M, Cheng X, Yi R, Gao D, Xiong J (2014): The binding receptors of Abeta: an alternative therapeutic target for Alzheimer's disease. Mol Neurobiol 53:455-471.

73. Han SH, Park JC, Mook-Jung I (2016): Amyloid beta-interacting partners in Alzheimer's disease: From accomplices to possible therapeutic targets. Prog Neurobiol 137:17-38.

74. De Felice FG, Velasco PT, Lambert MP, Viola K, Fernandez SJ, Ferreira ST, et al (2007): Abeta oligomers induce neuronal oxidative stress through an N-methyl-D-aspartate receptordependent mechanism that is blocked by the Alzheimer drug memantine. J Biol chem 282:11590-11601.

75. Zhao WQ, Santini F, Breese R, Ross D, Zhang XD, Stone DJ, et al (2010): Inhibition of calcineurin-mediated endocytosis and alpha-amino-3-hydroxy-5-methyl-4-

isoxazolepropionic acid (AMPA) receptors prevents amyloid beta oligomer-induced synaptic disruption. J Biol Chem 285:7619-7632.

76. Deutsch SI, Burket JA, Benson AD (2014): Targeting the alpha7 nicotinic acetylcholine receptor to prevent progressive dementia and improve cognition in adults with Down's syndrome. Prog Neuropsychopharmacol Biol Psychiatry 54:131-139.

77. Sturchler E, Galichet A, Weibel M, Leclerc E, Heizmann CW (2008): Site-specific blockade of RAGE-Vd prevents amyloid-beta oligomer neurotoxicity. J Neurosci 28:5149-5158.

78. Zhao WQ, De Felice FG, Fernandez S, Chen H, Lambert MP, Quon MJ, et al (2008): Amyloid beta oligomers induce impairment of neuronal insulin receptors. FASEB J 22:246-260.

79. Knowles JK, Rajadas J, Nguyen TV, Yang T, LeMieux MC, Vander GL, et al (2009): The p75 neurotrophin receptor promotes amyloid-beta(1-42)-induced neuritic dystrophy in vitro and in vivo. J Neurosci 29:10627-10637.

80. Yaar M, Zhai S, Pilch PF, Doyle SM, Eisenhauer PB, Fine RE, et al (1997): Binding of betaamyloid to the $\mathrm{p} 75$ neurotrophin receptor induces apoptosis. A possible mechanism for Alzheimer's disease. J Clin Invest 100:2333-2340.

81. Yu JT, Wang ND, Ma T, Jiang H, Guan J, Tan L (2011): Roles of beta-adrenergic receptors in Alzheimer's disease: implications for novel therapeutics. Brain Res Bull 84:111-117.

82. Magdesian MH, Carvalho MM, Mendes FA, Saraiva LM, Juliano MA, Juliano L, et al (2008): Amyloid-beta binds to the extracellular cysteine-rich domain of Frizzled and inhibits Wnt/beta-catenin signaling. J Biol chem 283:9359-9368.

83. Dinamarca MC, Di Luca M, Godoy JA, Inestrosa NC (2015): The soluble extracellular fragment of neuroligin-1 targets Abeta oligomers to the postsynaptic region of excitatory synapses. Biochem Biophys Res Commun 466:66-71.

84. Pujadas L, Rossi D, Andres R, Teixeira CM, Serra-Vidal B, Parcerisas A, et al (2014): Reelin delays amyloid-beta fibril formation and rescues cognitive deficits in a model of Alzheimer's disease. Nat Commun 5:3443.

85. Yanagisawa K, Ihara Y (1998): GM1 ganglioside-bound amyloid beta-protein in Alzheimer's disease brain. Neurobiol Aging 19:S65-S67. 
86. Kanekiyo T, Bu G (2014): The low-density lipoprotein receptor-related protein 1 and amyloid-beta clearance in Alzheimer's disease. Front Aging Neurosci 6:93.

87. Kam TI, Park H, Gwon Y, Song S, Kim SH, Moon SW, et al (2016): FcgammaRIlb-SHIP2 axis links Abeta to tau pathology by disrupting phosphoinositide metabolism in Alzheimer's disease model. Elife 5:e18691.

88. Thomas P, Pang Y, Dong J (2014): Enhancement of cell surface expression and receptor functions of membrane progestin receptor alpha (mPRalpha) by progesterone receptor membrane component 1 (PGRMC1): evidence for a role of PGRMC1 as an adaptor protein for steroid receptors. Endocrinology 155:1107-1119.

89. Fu AK, Hung KW, Huang H, Gu S, Shen Y, Cheng EY, et al (2014): Blockade of EphA4 signaling ameliorates hippocampal synaptic dysfunctions in mouse models of Alzheimer's disease. Proc Natl Acad Sci U S A 111:9959-9964.

90. Cisse M, Checler F (2015): Eph receptors: new players in Alzheimer's disease pathogenesis. Neurobiol Dis 73:137-149.

91. Purro SA, Galli S, Salinas PC (2014): Dysfunction of Wnt signaling and synaptic disassembly in neurodegenerative diseases. J Mol Cell Biol 6:75-80.

92. Rushworth JV, Griffiths HH, Watt NT, Hooper NM (2013): Prion protein-mediated toxicity of amyloid-beta oligomers requires lipid rafts and the transmembrane LRP1. J Biol Chem 288:8935-8951.

93. Bate C, Williams A (2011): Amyloid-beta-induced Synapse Damage Is Mediated via Crosslinkage of Cellular Prion Proteins. J Biol Chem 286:37955-37963.

94. Linden R (2017): The Biological Function of the Prion Protein: A Cell Surface Scaffold of Signaling Modules. Front Mol Neurosci 10:77.

95. Kaufman AC, Salazar SV, Haas LT, Yang J, Kostylev MA, Jeng AT, et al (2015): Fyn inhibition rescues established memory and synapse loss in Alzheimer mice. Ann Neurol 77:953-971.

96. Nygaard HB, Wagner AF, Bowen GS, Good SP, MacAvoy MG, Strittmatter KA, et al (2015): A phase $\mathrm{Ib}$ multiple ascending dose study of the safety, tolerability, and central nervous system availability of AZD0530 (saracatinib) in Alzheimer's disease. Alzheimers Res Ther 7:35.

97. Lesne S, Koh MT, Kotilinek L, Kayed R, Glabe CG, Yang A, et al (2006): A specific amyloid-beta protein assembly in the brain impairs memory. Nature 440:352-357.

98. Lashuel HA, Hartley D, Petre BM, Walz T, Lansbury PT, Jr. (2002): Neurodegenerative disease: amyloid pores from pathogenic mutations. Nature 418:291.

99. Walsh DM, Lomakin A, Benedek GB, Condron MM, Teplow DB (1997): Amyloid beta-protein fibrillogenesis - Detection of a protofibrillar intermediate. J Biol Chem 272:22364-22372.

100. Zou WQ, Xiao X, Yuan J, Puoti G, Fujioka H, Wang X, et al (2011): Amyloid beta interacts mainly with insoluble prion protein in the Alzheimer brain. J Biol Chem 286:15095-15105. 
101. Freir DB, Nicoll AJ, Klyubin I, Panico S, Mc Donald JM, Risse E, et al (2011): Interaction between prion protein and toxic amyloid beta assemblies can be therapeutically targeted at multiple sites. Nat Commun 2:336.

102. Caetano FA, Beraldo FH, Hajj GN, Guimaraes AL, Jurgensen S, Wasilewska-Sampaio AP, et al (2011): Amyloid-beta oligomers increase the localization of prion protein at the cell surface. J Neurochem 117:538-553.

103. Kudo W, Lee HP, Zou WQ, Wang X, Perry G, Zhu X, et al (2011): Cellular prion protein is essential for oligomeric Amyloid-beta-Induced neuronal cell death. Hum Mol Genet 21:11381144.

104. You H, Tsutsui S, Hameed S, Kannanayakal TJ, Chen L, Xia P, et al (2012): Abeta neurotoxicity depends on interactions between copper ions, prion protein, and N-methyl-D-aspartate receptors. Proc Natl Acad Sci U S A 109:1737-1742.

105. Hyeon JW, Kim SY, Park JS, Choi BY, Lee SM, Ju YR, et al (2012): The association between prion proteins and A beta(1-42) oligomers in cytotoxicity and apoptosis. Biochem Biophys Res Commun 424:214-220.

106. Rial D, Piermartiri TC, Duarte FS, Tasca Cl, Walz R, Prediger RD (2012): Overexpression of cellular prion protein $\left(\operatorname{PrP}^{C}\right)$ prevents cognitive dysfunction and apoptotic neuronal cell death induced by Amyloid-beta (Ab(1-40)) administration in mice. Neuroscience 215:79-89.

107. Ordonez-Gutierrez L, Torres JM, Gavin R, Anton M, Arroba-Espinosa Al, Espinosa JC, et al (2013): Cellular prion protein modulates beta-amyloid deposition in aged APP/PS1 transgenic mice. Neurobiol Aging 34:2793-2804.

108. Chen RJ, Chang WW, Lin YC, Cheng PL, Chen YR (2013): Alzheimer's Amyloid-beta oligomers rescue cellular prion protein induced Tau reduction via the Fyn pathway. ACS Chem Neurosci 4:1287-1296.

109. Ostapchenko VG, Beraldo FH, Mohammad AH, Xie YF, Hirata PH, Magalhaes AC, et al (2013): The Prion Protein ligand, Stress-Inducible Phosphoprotein 1, regulates Amyloid-beta oligomer toxicity. J Neurosci 33:16552-16564.

110. Rubel AA, Ryzhova TA, Antonets KS, Chernoff YO, Galkin A (2013): Identification of PrP sequences essential for the interaction between the PrP polymers and Abeta peptide in a yeast-based assay. Prion 7:469-476.

111. An K, Klyubin I, Kim Y, Jung JH, Mably AJ, O'Dowd ST, et al (2013): Exosomes neutralize synaptic-plasticity-disrupting activity of Abeta assemblies in vivo. Molecular Brain 6:47.

112. Nah J, Pyo JO, Jung S, Yoo SM, Kam TI, Chang J, et al (2013): BECN1/Beclin 1 is recruited into lipid rafts by prion to activate autophagy in response to amyloid beta 42. Autophagy 9:20092021.

113. Rushworth JV, Ahmed A, Griffiths HH, Pollock NM, Hooper NM, Millner PA (2014): A labelfree electrical impedimetric biosensor for the specific detection of Alzheimer's amyloid-beta oligomers. Biosens Bioelectron 56:83-90. 
114. Ganzinger KA, Narayan P, Qamar SS, Weimann L, Ranasinghe RT, Aguzzi A, et al (2014): Single-molecule imaging reveals that small Amyloid-beta oligomers interact with the cellular prion protein (PrP). Chembiochem 15:2515-2521.

115. Peters C, Espinoza MP, Gallegos S, Opazo C, Aguayo LG (2014): Alzheimer's Abeta interacts with cellular prion protein inducing neuronal membrane damage and synaptotoxicity. Neurobiol Aging 36:1369-1377.

116. West E, Osborne C, Nolan W, Bate C (2015): Monoacylated cellular prion proteins reduce Amyloid-beta-induced activation of cytoplasmic phospholipase A2 and synapse damage. Biology (Basel) 4:367-382.

117. Williams TL, Choi JK, Surewicz K, Surewicz WK (2015): Soluble prion protein binds isolated low molecular weight Amyloid-beta oligomers causing cyto-toxicity inhibition. ACS Chem Neurosci 6:1972-1980.

118. De Mario A, Castellani A, Peggion C, Massimino ML, Lim D, Hill AF, et al (2015): The prion protein constitutively controls neuronal store-operated $\mathrm{Ca}$ entry through Fyn kinase. Front Cell Neurosci 9:416.

119. Heiss JK, Barrett J, Yu Z, Haas LT, Kostylev MA, Strittmatter SM (2016): Early activation of experience-independent dendritic spine turnover in a mouse model of Alzheimer's disease. Cereb Cortex 27:3360-3674.

120. Beraldo FH, Ostapchenko VG, Caetano FA, Guimaraes AL, Ferretti GD, Daude N, et al (2016): Regulation of Amyloid beta oligomer binding to neurons and neurotoxicity by the complex prion protein/mGluR5. J Biol chem 291:21945-21955.

121. Pinnock EC, Jovanovic K, Pinto MG, Ferreira E, Dias BD, Penny C, et al (2015): LRP/LR antibody mediated rescuing of Amyloid-beta-induced cytotoxicity is dependent on $\mathrm{PrP}^{\mathrm{C}}$ in Alzheimer's disease. J Alzheimers Dis 49:645-657.

122. Sempou E, Biasini E, Pinzon-Olejua A, Harris DA, Malaga-Trillo E (2016): Activation of zebrafish Src family kinases by the prion protein is an amyloid-beta-sensitive signal that prevents the endocytosis and degradation of E-cadherin/beta-catenin complexes in vivo. Mol Neurodegener 11:18.

123. Haas LT, Salazar SV, Smith LM, Zhao HR, Cox TO, Herber CS, et al (2017): Silent allosteric modulation of mGluR5 maintains glutamate signaling while rescuing Alzheimer's mouse phenotypes. Cell Rep 20:76-88.

124. Nolan W, McHale-Owen H, Bate C (2017): Sialylated glycosylphosphatidylinositols suppress the production of toxic amyloid-beta oligomers. Biochem J 474:3045-3058.

125. West $E$, Osborne $C$, Bate $C$ (2017): The cholesterol ester cycle regulates signalling complexes and synapse damage caused by amyloid-beta. J Cell Sci 130: 3050-3059.

126. Zhang D, Qi Y, Klyubin I, Ondrejcak T, Sarell CJ, Cuello AC, et al (2017): Targeting glutamatergic and cellular prion protein mechanisms of amyloid beta-mediated persistent synaptic plasticity disruption: Longitudinal studies. Neuropharmacology 121:231-246. 
$A \beta$ dimer

$A \beta$ trimer

ADDL (Lambert et al., 2)

$A \beta^{*} 56$ (Lesné et al., 97)

TABFO (Stroud et al., 12)

Annular protofibril (Lashuel et al., 98)

ADDL (Hepler et al., 10)

ADDL (Laurén et al., 23)

Protofibril (Walsh et al., 99)

\begin{tabular}{|l|}
\hline \\
\hline
\end{tabular}

$10^{3}$

1,111111

$10^{4}$

1 1 11111

$\because 0$

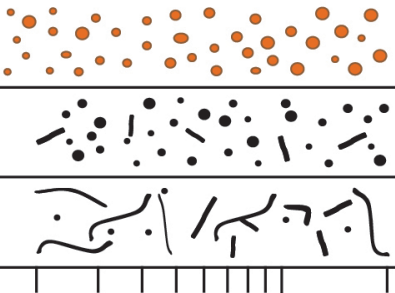

$10^{5}$

$10^{6}$

Molecular weight 


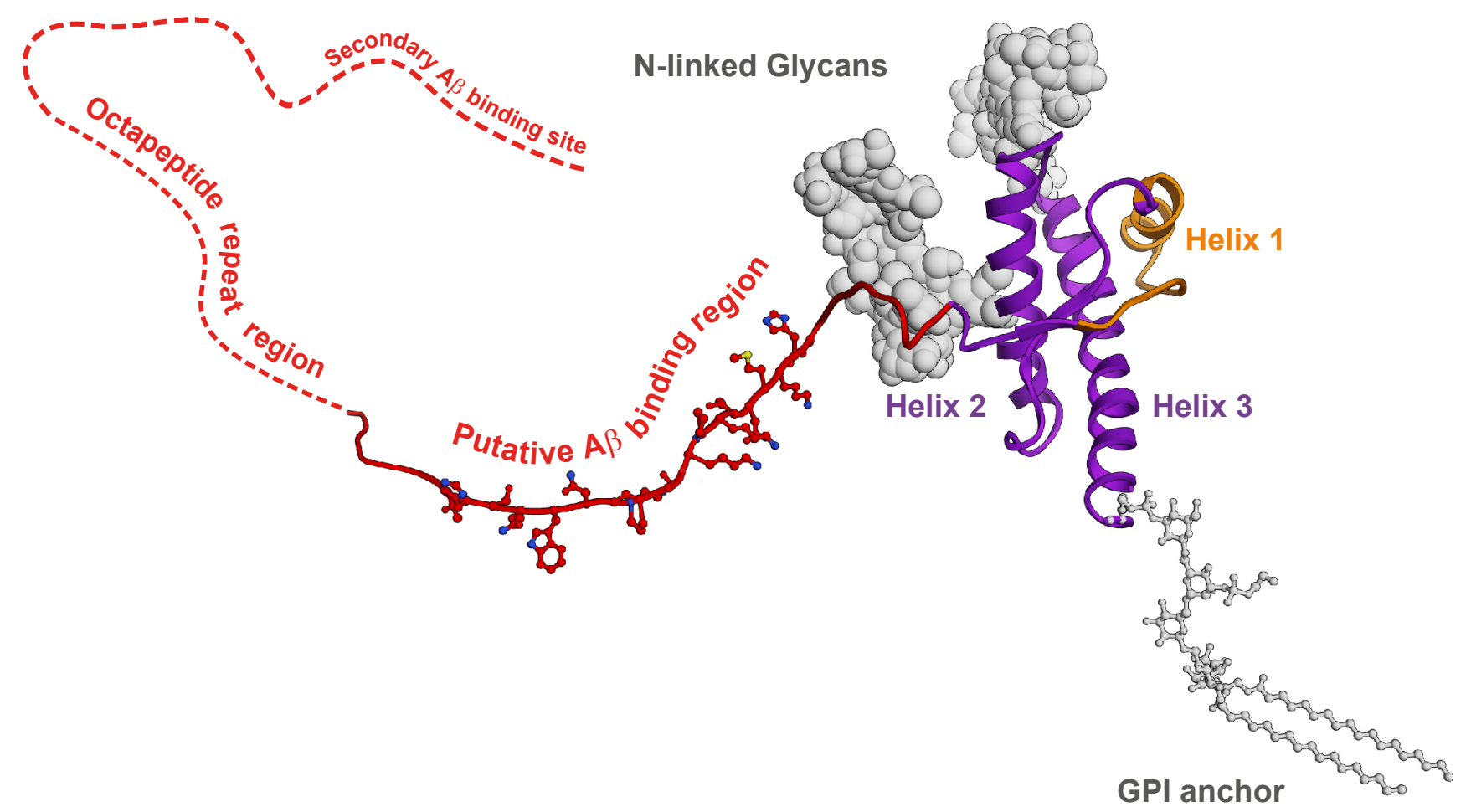




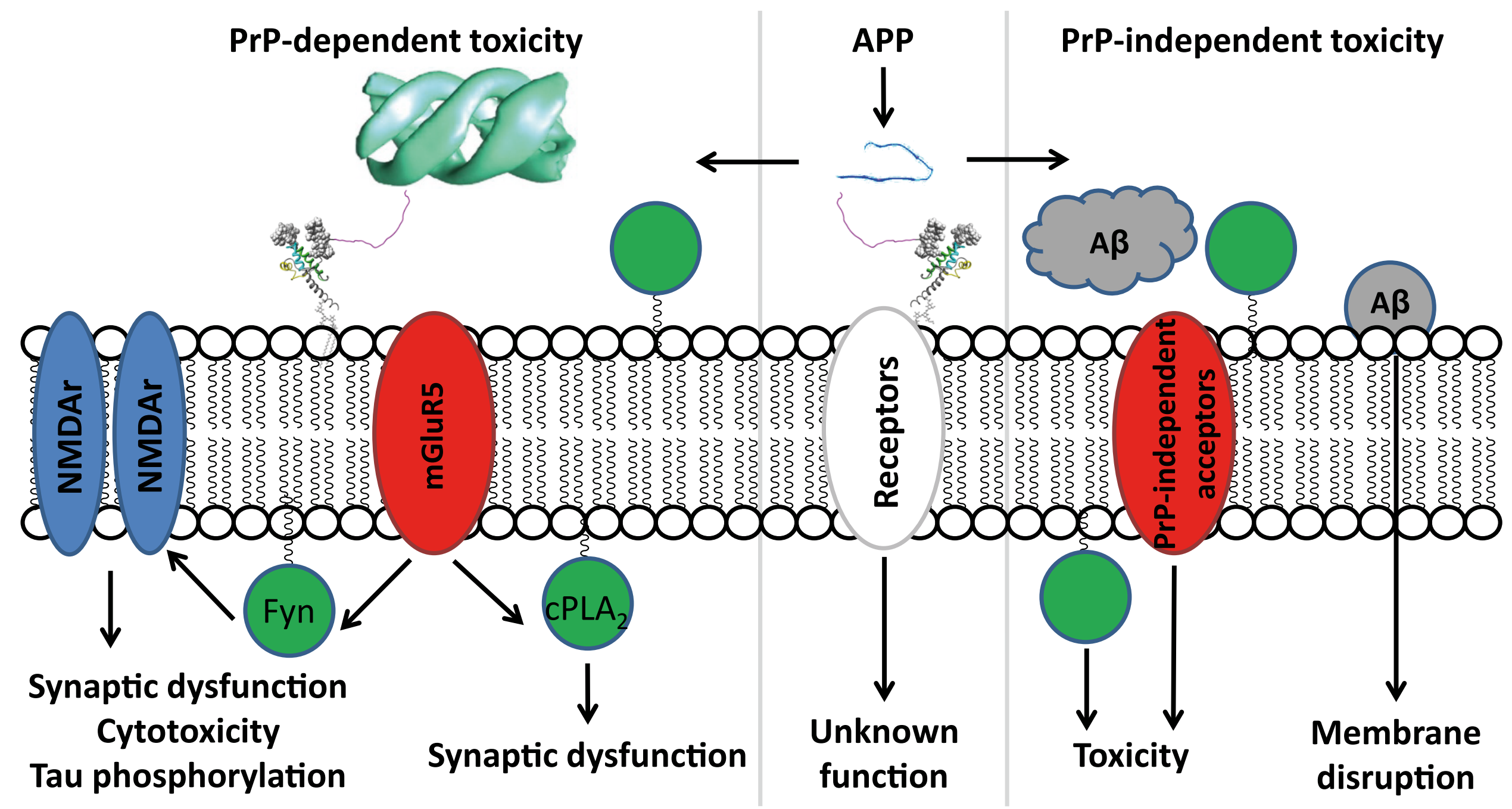

